\title{
Formation of a dipeptidyl arylamidase by Bacteroides splanchnicus NCTC 10825 with specificities towards glycylprolyl-x and valylalanine-x substrates
}

\author{
SANDRA MACFARLANE and G. T. MACFARLANE \\ MRC Dunn Clinical Nutrition Centre, Hills Road, Cambridge CB2 2DH
}

\begin{abstract}
Bacteroides splanchnicus in common with several members of the $B$. fragilis group constitutively produced a number of protein and peptide hydrolysing enzymes. Amongst the most active was an arylamidase, which specifically hydrolysed the dipeptidyl chromogenic substrates glycylprolyl $p$-nitroanilide (GPRPNA), glycylprolyl $\beta$-naphthylamide (GPBNA) and valylalanine $p$-nitroanilide (VAPNA), and had some proteolytic activity towards azocasein. No activity was detected against proline $\beta$-naphthylamide, glycine, valanine or alanine $p$-nitroanilides. Physiological studies showed that the enzyme was largely cell-associated during exponential growth in batch culture, but was progressively released by the bacteria before the cells entered stationary phase. Glycylprolyl arylamidase (GPA) was completely cell-bound during growth in continuous culture, where synthesis increased concomitantly with dilution rate (specific growth rate) in both carbon- and nitrogen-limited chemostats. Gel-filtration chromatography of $B$. splanchnicus cell extracts yielded a single peak of GPA activity, with an apparent molecular mass of $c$. $160 \mathrm{kDa}$, while one peak of enzyme activity was eluted by $0.3 \mathrm{M}$ $\mathrm{NaCl}$ during cation-exchange chromatography. Activity staining of SDS polyacrylamide gels showed a single GPA band at $80 \mathrm{kDa}$, suggesting that the enzyme was a dimer. Two fractions of GPA activity were recorded during preparative isoelectric focusing with apparent isoelectric points of pH 3.51 (fraction 3) and 3.95 (fraction 6), indicating the possible existence of GPA isoenzymes. GPRPNA, VAPNA and azocasein were hydrolysed by the major fraction (fraction 3), while only the p-nitroanilide substrates were hydrolysed by fraction 6. Studies with the partially purified enzyme obtained from gel filtration columns showed a relatively broad $\mathrm{pH}$ optimum at 7.5-8.2. Inhibition experiments demonstrated that while aspartic (pepstatin $A$ ), thiol (iodoacetate) and metalloprotease (EDTA, cysteine) inhibitors had little effect on hydrolysis of glycylproline $p$-nitroanilide, GPA was strongly inhibited $($ c. $80 \%)$ by $5 \mathrm{~mm}$ phenylmethylsulphonyl fluoride (PMSF), indicating it to be a serine enzyme.
\end{abstract}

\section{Introduction}

Bacteroides splanchnicus is an anaerobic gram-negative rod and is a common inhabitant of the human large intestine, occurring in numbers in excess of $10^{10} / \mathrm{g}$ dry weight of gut contents, in some individuals $[1,2]$. The bacterium is not a member of the $B$. fragilis group (genus Bacteroides sensu stricto), which it resembles metabolically, and is differentiated from these organisms on the basis of its inability to grow on sucrose and certain other disaccharides [3]. Previous studies have shown that $B$. splanchnicus, together with some

Received 18 Sept. 1996; accepted 4 Nov. 1996. Corresponding author: Dr G. T. Macfarlane. members of the B. fragilis group, is strongly proteolytic $[4,5]$, and is nutritionally versatile with respect to its nitrogen requirements, being able to utilise a variety of inorganic and organic $\mathrm{N}$-containing compounds for growth, including pancreatic endopeptidases such as trypsin and chymotrypsin [6].

At present, little is known of the factors that control proteolysis in the large intestine, or the ecological significance of proteolysis. The ability of various bacteroides to scavenge pancreatic and other host secretions may confer a competitive advantage on these organisms during growth in the large bowel [6]. The synthesis and activities of peptidolytic enzymes by human colonic bacteriodes is of interest both from 
the viewpoint of the turnover of organic N-containing compounds in the large bowel [7-9] and also because of their potential role in pathogenicity $[10,11]$. For example, in bacterial overgrowth syndromes, peptidolytic enzymes produced by colonic bacteroides have been reported to destroy brush border glycosidases [12].

Previous work has shown that B. splanchnicus NCTC 10825 forms several peptide hydrolases of the thiol, serine, and possibly, the metalloprotease type, and that these enzymes exhibited arylamidase activity against chromogenic substrates such as valylalanine $p$-nitroanilide (VAPNA) and glycylprolyl $p$-nitroanilide (GPRPNA) [6]. The objectives of this study were to investigate the physiological factors affecting formation of dipeptidyl arylamidases in this organism, with a view to understanding how their synthesis might be regulated in the large intestine, and to study certain of the biochemical attributes of the enzymes.

\section{Materials and methods}

\section{Organisms}

B. splanchnicus NCTC 10825, B. vulgatus NCTC 11154, B. fragilis NCTC 10584, B. thetaiotaomicron NCTC 10582 and $B$. ovatus NCTC 11153 were obtained from the National Collection of Type Cultures, Public Health Laboratory Service, 61 Colindale Avenue, London. B. fragilis NCFB 2217 was purchased from the National Collection of Food Bacteria, Reading.

\section{Arylamidase and $\beta$-naphthylamidase activities in Bacteroides spp.}

Bacteria were grown anaerobically in Wilkins-Chalgren broth. Mid-exponential phase cells were pelleted by centrifugation $\left(20000 \mathrm{~g}, 30 \mathrm{~min}, 4^{\circ} \mathrm{C}\right)$ and were washed and resuspended in anaerobic sodium phosphate buffer $(0.1 \mathrm{M}, \mathrm{pH} 7.4)$. The abilities of washed bacteria to hydrolyse a range of $p$-nitroanilide and $\beta$ naphthylamide substrates (see Table 1) was investigated by methods described by Gibson and Macfarlane [13].

\section{Growth and arylamidase formation by $B$. splanchnicus in batch culture}

B. splanchnicus was grown in 280-ml (working volume) glass fermentation vessels at $37^{\circ} \mathrm{C}$. Cultures were stirred magnetically and $\mathrm{pH}$ was automatically controlled at 6.5 by procedures described previously [14]. Anaerobic conditions were maintained by sparging the cultures with oxygen-free $\mathrm{CO}_{2}(2.4 \mathrm{~L} / \mathrm{h})$. The culture medium consisted of $(\mathrm{g} / \mathrm{L})$ : glucose, 10.0; peptone water, $0.25 ; \mathrm{NH}_{4} \mathrm{Cl}, 0.5 ; \mathrm{NaCl}, 4.5 ; \mathrm{KH}_{2} \mathrm{PO}_{4}$, $4.0 ; \mathrm{MgCl}_{2} .6 \mathrm{H}_{2} \mathrm{O}, 0.10 ; \mathrm{CaCl}_{2} .2 \mathrm{H}_{2} \mathrm{O}, 0.10 ; \mathrm{CoCl}_{2}$. $6 \mathrm{H}_{2} \mathrm{O}, \quad 0.10 ; \quad \mathrm{MnCl}_{2} .4 \mathrm{H}_{2} \mathrm{O}, 0.10 ;$ cysteine, 0.80 ; $\mathrm{NaHCO}_{3}, 1.5$; haemin, 0.01; vitamin $\mathrm{B}_{12}, 0.005$;
$\mathrm{FeSO}_{4} .7 \mathrm{H}_{2} \mathrm{O}$, 0.001; resazurin, 0.001. The culture medium was autoclaved $\left(121^{\circ} \mathrm{C}, 15 \mathrm{~min}\right)$ and cooled under a stream of oxygen-free $\mathrm{CO}_{2}$ before use. Bacterial growth was monitored by following culture absorbance changes at $650 \mathrm{~nm}$.

Samples were taken periodically from the fermenters for measurements of glycylprolyl arylamidase (GPA) activities during the growth cycle. Bacteria were harvested as above. Cell-free culture supernates were also retained. Crude cell extracts were prepared by disrupting the bacteria during two passages through a French pressure cell $\left(1.1 \times 10^{5} \mathrm{kPa}\right)$. The efficiency of cell destruction was confirmed by microscopy.

GPA activities associated with whole cells, in culture supernates and bacterial cell extracts were determined as before. All activities were corrected for different sample dilutions to allow quantitative comparisons to be made between cell-associated and extracellular enzyme activities.

\section{Growth in continuous culture}

B. splanchnicus was grown in 500-ml (working volume) chemostats. Temperature, $\mathrm{pH}$ and anaerobic conditions were regulated in the same way as in the batch culture experiments described earlier. The culture medium was that used in the batch culture studies; however, glucose and $\mathrm{NH}_{4} \mathrm{Cl}$ concentrations in nitrogen- and carbon-limited growth media were 10.0 and $0.5 \mathrm{~g} / \mathrm{L}$, and 5.0 and $1.0 \mathrm{~g} / \mathrm{L}$, respectively. Dilution rates ranged between 0.025 and $0.29 / \mathrm{h}$. Cultures were allowed to equilibrate for at least eight complete volume changes in the chemostats, at each dilution rate, before sampling to ensure that steady state conditions had been achieved. Different dilution rates were applied to the chemostats at random. Samples were taken at different specific growth rates for measurements of cell-associated and extracellular arylamidase activities (GPRPNA substrate), as outlined above.

\section{Inhibitor experiments}

The effects of various natural and synthetic protease inhibitors (see Table 2) on arylamidase (GPRPNA and VAPNA substrates) and general protease (azocasein substrate) activities were investigated with crude cell extracts from exponential phase B. splanchnicus, employing procedures described in earlier studies [15].

\section{Isoelectric focusing studies}

Preparative isoelectric focusing of $B$. splanchnicus GPA was performed with the Rotofor system (BioRad). Bacterial cell extracts $(20 \mathrm{ml})$ were dialysed under anaerobic conditions for $12 \mathrm{~h}$ at $4^{\circ} \mathrm{C}$ against distilled water $(5 \mathrm{~L})$ that had been boiled and cooled under oxygen-free nitrogen. They were subsequently diluted 
to $60 \mathrm{ml}$ with distilled water and ampholytes (BioRad), $\mathrm{pH} 2.0-6.5$, were added to a concentration of $0.5 \%$ $\mathrm{v} / \mathrm{v}$. Samples were run on the Rotofor cell at $2^{\circ} \mathrm{C}$ for between 3 and $4 \mathrm{~h}$ at a constant power setting of $12 \mathrm{~W}$. Initial and final currents ranged between 24-26 and 13-15 mA. Initial and final voltages were $420-460$ and $870-940 \mathrm{~V}$, respectively. The electrolytes were $0.075 \mathrm{M}$ $\mathrm{H}_{3} \mathrm{PO}_{4}$ (anode) and $0.075 \mathrm{M} \mathrm{NaOH}$ (cathode). After harvesting, the $\mathrm{pH}$ in each sample tube was recorded immediately, before arylamidase (GPRPNA and VAPNA substrates) and protease (azocasein substrate) measurements were made.

\section{Gel-filtration chromatography}

GPA in cell extracts of $B$. splanchnicus was separated by HPLC, with an $0.8 \times 30 \mathrm{~cm}$ TSK $3000 \mathrm{SW}$ Ultropac column (LKB). The samples were isocratically eluted with $0.1 \mathrm{M}$ sodium phosphate buffer containing $0.1 \mathrm{M} \mathrm{NaCl}$ and $1 \mathrm{mM}$ mercaptoethanol, at a flow rate of $0.2 \mathrm{ml} / \mathrm{min}$. Column effluent was monitored for protein at $208 \mathrm{~nm}$. Fractions $(0.2 \mathrm{ml})$ were collected and assayed for activity against GPRPNA. The system was calibrated for estimations of mol. wt with a range of protein standards obtained from BioRad: amylase (200 kDa), alcohol dehydrogenase $(150 \mathrm{kDa})$, bovine serum albumin $(66 \mathrm{kDa})$, ovalbumin $(45 \mathrm{kDa})$ and lysozyme $(14.5 \mathrm{kDa})$.

\section{Cation-exchange chromatography}

Samples from the gel-filtration column were loaded on to a 20-cm glass column containing CM 52 (Whatman). Samples were eluted with $0.05 \mathrm{M}$ sodium acetate buffer ( $\mathrm{pH} 4.5$ ), with a linearly increasing concentration of $\mathrm{NaCl}(0.1-0.4 \mathrm{M})$ at a flow rate of $80 \mathrm{ml} / \mathrm{h}$. Protein was detected in the eluant with an UV monitor at $208 \mathrm{~nm}$. Arylamidase activity against GPRPNA and VAPNA was detected as before.

\section{$S D S-P A G E$}

This was carried out in the presence of SDS $0.1 \% \mathrm{w} / \mathrm{v}$, by procedures described by Laemmli [16]. A polyacrylamide $4 \%$ stacking gel and separating $7.5 \%$ gel were used. After running, the gels were renatured by incubation in $25 \mathrm{mM}$ Tris buffer $(\mathrm{pH} 8.0)$ containing Lubrol $0.5 \% \mathrm{w} / \mathrm{v}$ and Triton X100 $0.5 \% \mathrm{v} / \mathrm{v}$ for $2 \mathrm{~h}$ at room temperature. The buffer was discarded and replaced, and the gels left for a further $14 \mathrm{~h}$ at $4^{\circ} \mathrm{C}$. The gels were then incubated in the Tris buffer with Lubrol $0.05 \% \mathrm{w} / \mathrm{v}$ for $1 \mathrm{~h}$. This was followed by another incubation $(1 \mathrm{~h})$ with $0.1 \mathrm{M}$ Tris buffer $(\mathrm{pH}$ 6.5 ). The gels were subsequently cut into two pieces: one half was conventionally stained for protein with Coomassie Brilliant Blue R $0.2 \%$, the other was stained for arylamidase activity by flooding with a solution of GPRPNA ( $5 \mathrm{mM}$ ) in the Tris buffer. The gels were wrapped in clear plastic film and incubated for $4-6 \mathrm{~h}$ at $37^{\circ} \mathrm{C}$. Enzyme activity was visualised by the appearance of faint yellow bands, resulting from release of $p$-nitroaniline. The following mol.wt markets (Sigma) were used: myosin $(205 \mathrm{kDa}), \beta$-galactosidase $(116 \mathrm{kDa})$, phosphorylase $\mathrm{B}(97.4 \mathrm{kDa})$, bovine serum albumin $(66 \mathrm{kDa})$, egg albumin $(445 \mathrm{kDa})$ and carbonic anhydrase $(29 \mathrm{kDa})$.

\section{Effects of $p H$ and PMSF on GPA}

These studies were done with partially purified enzyme preparations obtained from gel-filtration chromatography samples. In the $\mathrm{pH}$ experiments, samples were preincubated at $37^{\circ} \mathrm{C}$ for $15 \mathrm{~min}$ in $0.1 \mathrm{M}$ Tris buffer at a range of $\mathrm{pH}$ values from 6.0 to 10.0 , before addition of GPRPNA substrate. Measurements of enzyme activity were made after incubation for $2 \mathrm{~h}$ at $37^{\circ} \mathrm{C}$ as outlined previously.

To confirm that GPA was sensitive to PMSF, samples from the gel-filtration column were pre-incubated with various concentrations of the inhibitor $(1-5 \mathrm{mM})$ for $15 \mathrm{~min}$ at $37^{\circ} \mathrm{C}$ before adding GPRPNA substrate. Arylamidase assays were then done as before.

\section{Protein measurements}

Protein concentrations in bacterial cell extracts were estimated by the Lowry method, with bovine serum albumin as standard.

\section{Determinations of culture dry weights}

These were made as described by Degnan and Macfarlane [17].

\section{Chemicals}

Unless stated otherwise, all chemicals were obtained from Sigma. Bacteriological culture media were purchased from Oxoid.

\section{Results}

\section{Arylamidase activities in human colonic bacteroides}

Data in Table 1 show arylamidase and $\beta$-naphthylamidase activities of proteolytic enzymes formed by several human intestinal Bacteroides isolates. Notably, all species examined, with the exception of $B$. thetaiotaomicron, exhibited high levels of hydrolytic activity against the dipeptidyl substrates GPRPNA and VAPNA, while $B$. splanchnicus also hydrolysed glycylprolyl $\beta$-naphthylamide (GP $\beta$ NA). No significant activity was detected when the dipeptidyl moieties were substituted with individual amino acids, or when glycine $p$-nitroanilide, alanine $p$-nitroanilide, valine $p$-nitroanilide and prolyl $\beta$-naphthylamide were used as substrates, although leucine $p$-nitroanilide was hydrolysed to some extent by all species. No activity 
Table 1. Arylamidase activities of proteolytic enzymes formed by human intestinal bacteroides

\begin{tabular}{|c|c|c|c|c|c|c|c|c|c|c|c|}
\hline \multirow[b]{2}{*}{ Strain } & \multicolumn{11}{|c|}{ nmol $p$-nitroaniline or $\beta$-naphthylamine released $/ \mathrm{h} / \mathrm{mg}$ (dry weight) cells } \\
\hline & LPNA & VAPNA & GPRPNA & BAPNA & GPPNA & $\mathrm{SA}_{3} \mathrm{PNA}$ & GPNA & APNA & VPNA & GP $\beta \mathrm{NA}$ & $\mathrm{P} \beta \mathrm{NA}$ \\
\hline $\begin{array}{l}\text { B. fragilis } \\
\text { NCFB } 2217\end{array}$ & 22 & 368 & 291 & - & - & - & - & - & - & NT & - \\
\hline $\begin{array}{l}\text { B. fragilis } \\
\text { NCTC } 10584\end{array}$ & 10 & 140 & 125 & - & - & - & - & - & - & NT & NT \\
\hline $\begin{array}{l}\text { B. vulgatus } \\
\text { NCTC } 11154\end{array}$ & 2 & 142 & 131 & - & - & - & - & - & - & NT & NT \\
\hline $\begin{array}{l}\text { B. ovatus } \\
\text { NCTC } 11153\end{array}$ & 1 & 141 & 146 & - & - & - & - & - & - & NT & NT \\
\hline $\begin{array}{l}\text { B. thetaiotaomicron } \\
\text { NCTC } 10582\end{array}$ & 1 & 48 & 41 & - & - & - & - & - & - & $\mathrm{NT}$ & NT \\
\hline $\begin{array}{l}\text { B. splanchnicus } \\
\text { NCTC } 10825\end{array}$ & 17 & 296 & 281 & - & - & - & - & - & - & 276 & - \\
\hline
\end{tabular}

LPNA, leucine $p$-nitroanilide; VAPNA, valylalanine $p$-nitroanilide; GPRPNA, glycylprolyl $p$-nitroanilide; BAPNA, benzoylarginine $p$ nitroanilide; GPPNA, glutarylphenylalanine $p$-nitroanilide; $\mathrm{SA}_{3} \mathrm{PNA}$, succinylalanylalanylalanine $p$-nitroanilide; GPNA, glycyl $p$-nitroanilide; APNA, alanine $p$-nitroanilide; VPNA, valine $p$-nitroanilide; GP $\beta$ NA, glycylprolyl $\beta$-naphthylamide; P $\beta$ NA, prolyl $\beta$-naphthylamide; - , no activity detected; NT, not tested; results are means of two determinations.

was observed against benzoylarginine $p$-nitroanilide, glutarylphenylalanine $p$-nitroanilide or succinylalanylalanylalanine $p$-nitroanilide.

\section{Batch culture studies on production of glycylprolyl arylamidase in B. splanchnicus}

Studies on glycylprolyl arylamidase (GPA) formation in batch cultures of $B$. splanchnicus demonstrated that high levels of the enzyme accumulated intracellularly during exponential growth (Fig. 1), while lower activities were detected with whole cells. However, towards the end of exponential growth, considerable amounts of GPA were released into the culture medium. Enzyme activities associated with whole bacteria changed little as intracellular enzymes were released.

\section{Expression of B. splanchnicus GPA in continuous culture}

In chemostat culture, higher levels of GPA synthesis were observed in nitrogen-limited vessels at low

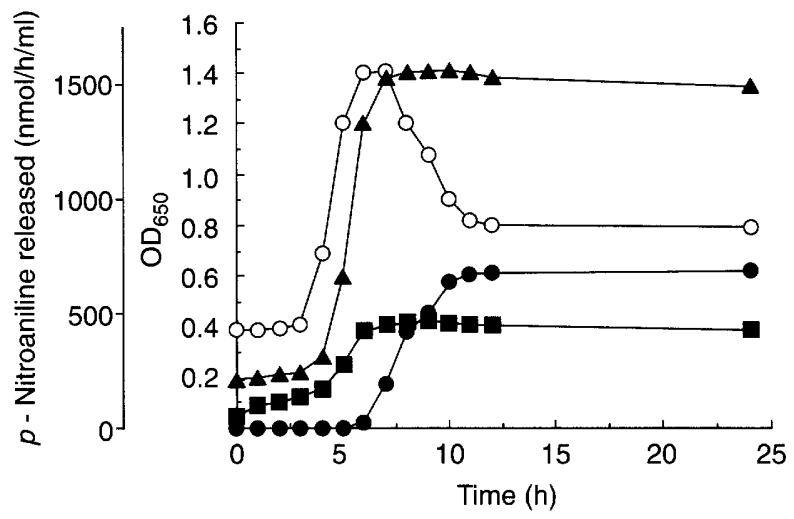

Fig. 1. Glycylprolyl arylamidase activities in batch cultures of $B$. splanchnicus; $\mathrm{A}_{650}(\boldsymbol{\Delta})$, enzyme activity associated with whole cells ( $\mathbf{\square}$ ), enzyme activity in bacterial cell extracts $(\bigcirc)$, extracellular enzyme activity (๑). Results are mean values obtained from two separate experiments. specific growth rates $(\mu)$, but enzyme formation was growth rate-associated in both carbon- and nitrogenlimited bacteria, and increased concomitantly with dilution rate (Fig. 2). Extracellular GPA activity was not detected in the chemostats, except at very low dilution rates $(D=<0.03 \mathrm{~h})$ where trace levels were found.

\section{Inhibitor studies}

Studies with a variety of protease inhibitors (Table 2) showed that hydrolysis of GPRPNA and VAPNA was strongly inhibited by PMSF and to a lesser degree by thimerosal. No effects were observed with aspartic or metalloprotease inhibitors. General protease activity, as indicated by azocasein hydrolysis, was also inhibited to a notable degree by PMSF; however, thimerosal was the most effective protease inhibitor, whilst significant reductions in proteolysis were also seen with iodoacetate, EDTA and cysteine.

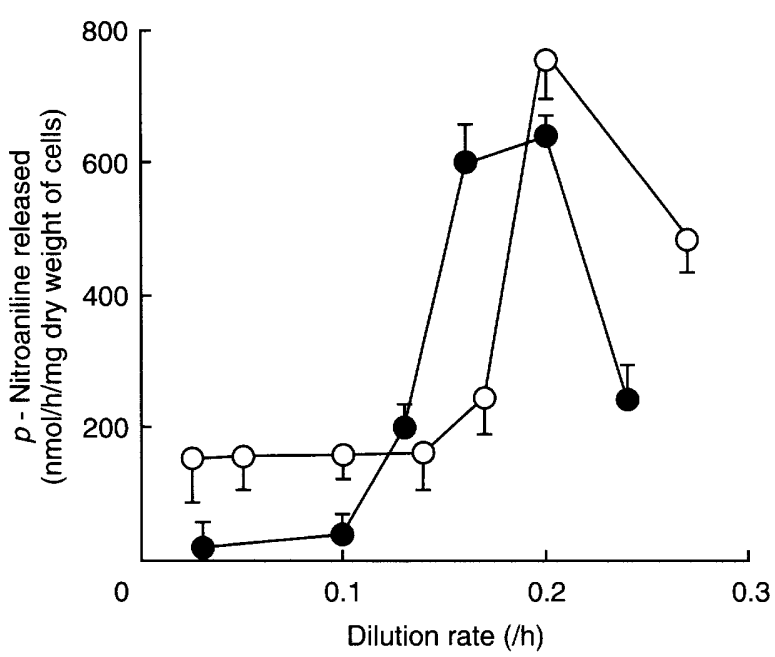

Fig. 2. Glycylprolyl arylamidase production in carbon$(O)$ and nitrogen-(O) limited B. splanchnicus at different specific growth rates $(\mu)$ in continuous culture. Results are means of between two-to-four measurements and SD. 
Table 2. Effect of inhibitors on proteolytic and arylamidase activities of B. splanchnicus

\begin{tabular}{|c|c|c|c|c|c|c|}
\hline \multirow[b]{2}{*}{ Inhibitor } & \multirow{2}{*}{$\begin{array}{c}\text { Assay } \\
\text { concentration }\end{array}$} & \multicolumn{3}{|c|}{ Percentage inhibition of substrate hydrolysis } & \multirow{2}{*}{$\begin{array}{l}\text { Protease } \\
\text { inhibited }\end{array}$} & \multirow[b]{2}{*}{ Reference } \\
\hline & & GPRPNA & VAPNA & Azocasein & & \\
\hline $\begin{array}{l}\text { Soybean trypsin } \\
\text { inhibitor }\end{array}$ & $100 \mu \mathrm{g} / \mathrm{ml}$ & - & - & - & Trypsin-like & Hazlewood and Edwards [18] \\
\hline Chymostatin & $250 \mu \mathrm{g} / \mathrm{ml}$ & - & - & - & Chymotrypsin-like & Umezawa and Aoyagi [19] \\
\hline PMSF & $5 \mathrm{mM}$ & $76.0 \pm 5.8$ & $78.1 \pm 4.3$ & $49.3 \pm 4.0$ & Serine proteases & Barrett $[20]$ \\
\hline Pepstatin A & $50 \mu \mathrm{g} / \mathrm{ml}$ & - & - & - & Aspartic proteases & Umezawa and Aoyagi [19] \\
\hline Elastinal & $8 \mu \mathrm{M}$ & - & - & - & Elastase & Umezawa and Aoyagi [19] \\
\hline EDTA & $5 \mathrm{mM}$ & - & - & 18.3 & Metalloproteases & Matsubara and Feder [21] \\
\hline Cysteine & $2 \mathrm{mM}$ & - & - & 14.7 & Metalloproteases & Siefter and Harper [22] \\
\hline Thimerosal & $5 \mathrm{~mm}$ & $52.1 \pm 5.1$ & $63.7 \pm 2.9$ & $70.7 \pm 6.2$ & Thiol proteases & Webb [23] \\
\hline Iodoacetate & $5 \mathrm{mM}$ & $7.4 \pm 1.8$ & - & $26.3 \pm 3.5$ & Thiol proteases & Barrett [20] \\
\hline
\end{tabular}

Organisms were harvested from batch cultures during the exponential phase of growth. Measurements of protease and arylamidase activities were made with cell extracts, as described in Materials and methods. Results are means of three determinations \pm SD. GPRPNA, glycylproline $p$-nitroanilide; VAPNA, valylalanine $p$-nitroanilide; PMSF, phenylmethylsulphonyl fluoride; -, no inhibition.

\section{Protein purification experiments}

In experiments aimed at further characterising $B$. splanchnicus GPA, preparative isoelectric focusing of cell extracts showed a major peak of enzyme activity in tube 3, corresponding to a $\mathrm{pH}$ of 3.51 , for both GPRPNA and VAPNA hydrolysis (Fig. 3). A minor peak of GPRPNA, and VAPNA activity also occurred in tube 6 ( $\mathrm{pH} 3.95)$. Azocasein was hydrolysed by tube 3 only.

Gel filtration of $B$. splanchnicus cell extracts by HPLC gave only one peak of activity against both GPRPNA and VAPNA, with an approximate mol. wt of $160 \mathrm{kDa}$ (Fig. 4), while cation-exchange chromatography yielded one peak of activity against GPRPNA,

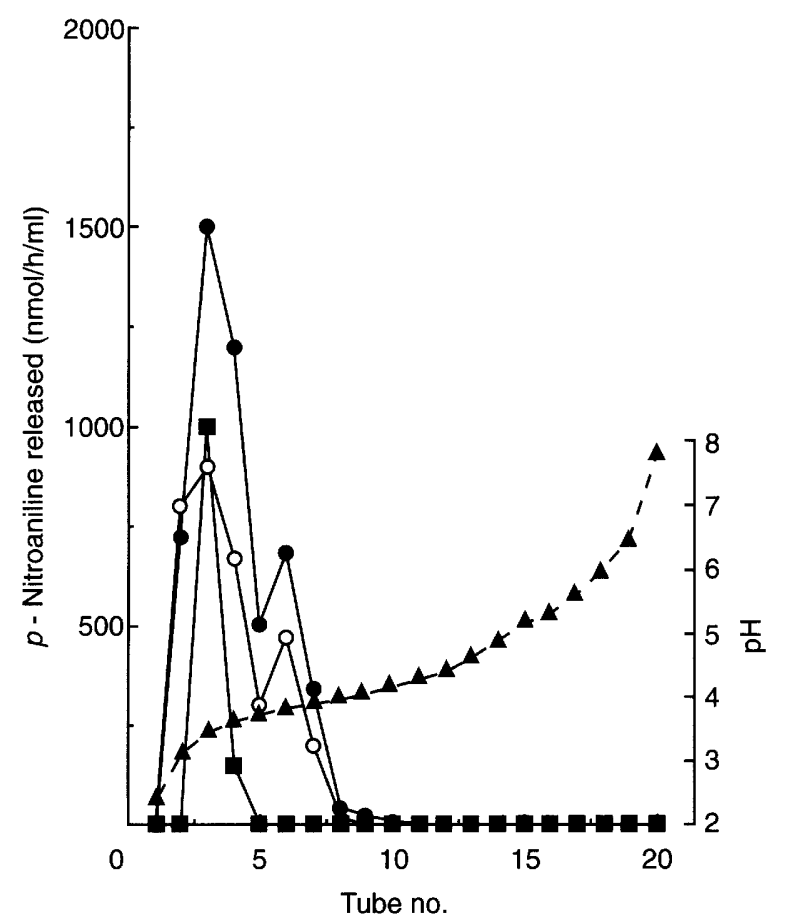

Fig. 3. Preparative isoelectric focusing of cell extracts of B. splanchnicus; GPRPNA hydrolysis (O), VAPNA hydrolysis $(\mathrm{O})$, azocasein hydrolysis ( $\mathbf{\square})$, $\mathrm{pH}$ gradient $(\boldsymbol{\Delta})$. Results are means of two experiments. which was eluted from the column by $0.3 \mathrm{M} \mathrm{NaCl}$ (Fig. 5). This was also the only peak of VAPNA hydrolysis (data not shown). SDS-PAGE (Fig. 6) resulted in one band of GPA activity on the gels, with an estimated molecular mass of $c .80 \mathrm{kDa}$.

\section{Effects of PMSF and pH on partially purified GPA}

Inhibitor studies with partially purified enzyme preparations obtained from gel filtration chromatography columns demonstrated that PMSF was inhibitory to GPA in a concentration-dependent way, with $3-5 \mathrm{mM}$ inhibitor reducing enzyme activity by c. $80 \%$ (Fig. 7). Measurements to determine the $\mathrm{pH}$ optimum of GPRPNA hydrolysis with these enzyme preparations (Fig. 8) showed a broad band of GPA activity in the neutral to slightly alkaline $\mathrm{pH}$ range (7.5-8.2).

\section{Discussion}

Bacterial arylamidases catalyse hydrolysis of N-terminal amino acid residues of $p$-nitroanilide and $\beta$ naphthylamide substrates. A number of arylamidase activities were found to be associated with $B$. splanchnicus, which hydrolysed four of $11 p$-nitroanilide and $\beta$-naphthylamide test substrates (Table 1). A similar pattern of hydrolysis was also observed in several members of the $B$. fragilis group. The inability of these organisms to hydrolyse BAPNA, GPPNA and $\mathrm{SA}_{3}$ PNA demonstrated that peptidolytic enzymes formed by human colonic bacteroides do not manifest trypsin-, chymotrypsin- or elastase-like properties.

Various factors are known to be involved in regulating peptidolytic activities in micro-organisms, including end-product inhibition of enzyme activities, induction of enzyme synthesis and catabolite repression of enzyme synthesis [24]. Although GPA formation was constitutive in $B$. splanchnicus, the process was markedly influenced by nutrient availability and cultural conditions. Batch culture experiments showed 


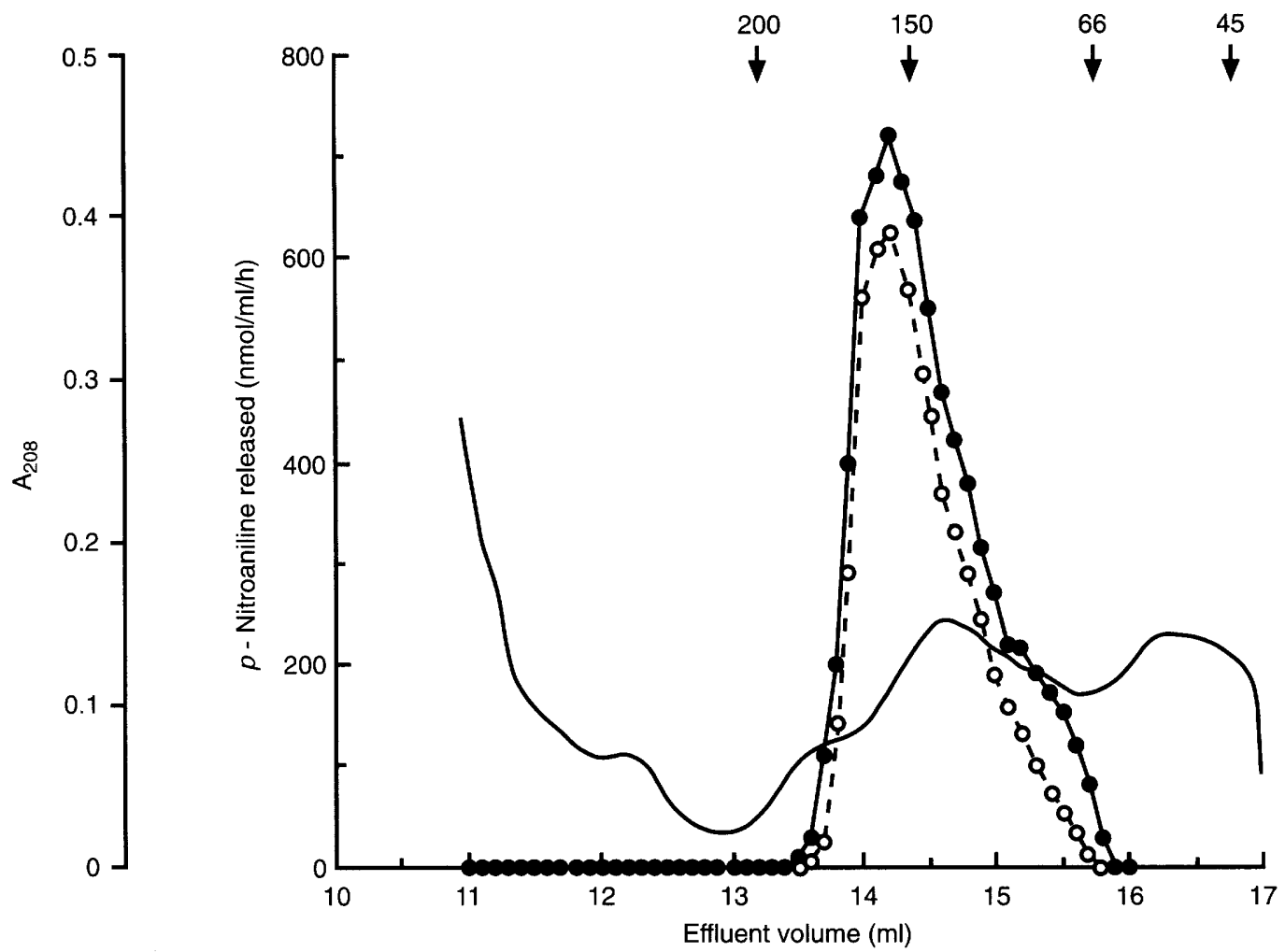

Fig. 4. Gel-filtration chromatography of cell extracts; GPRPNA hydrolysis (๑), VAPNA hydrolysis (O), protein absorbance at $208 \mathrm{~nm}$ shown by the solid line. Mol. wt standards (kDa): A, amylase (200); B, alcohol dehydrogenase (150); C, bovine serum albumin (66); D, ovalbumin (45). Lysozyme (14.5), which is not shown, was also used to construct the standard curve.

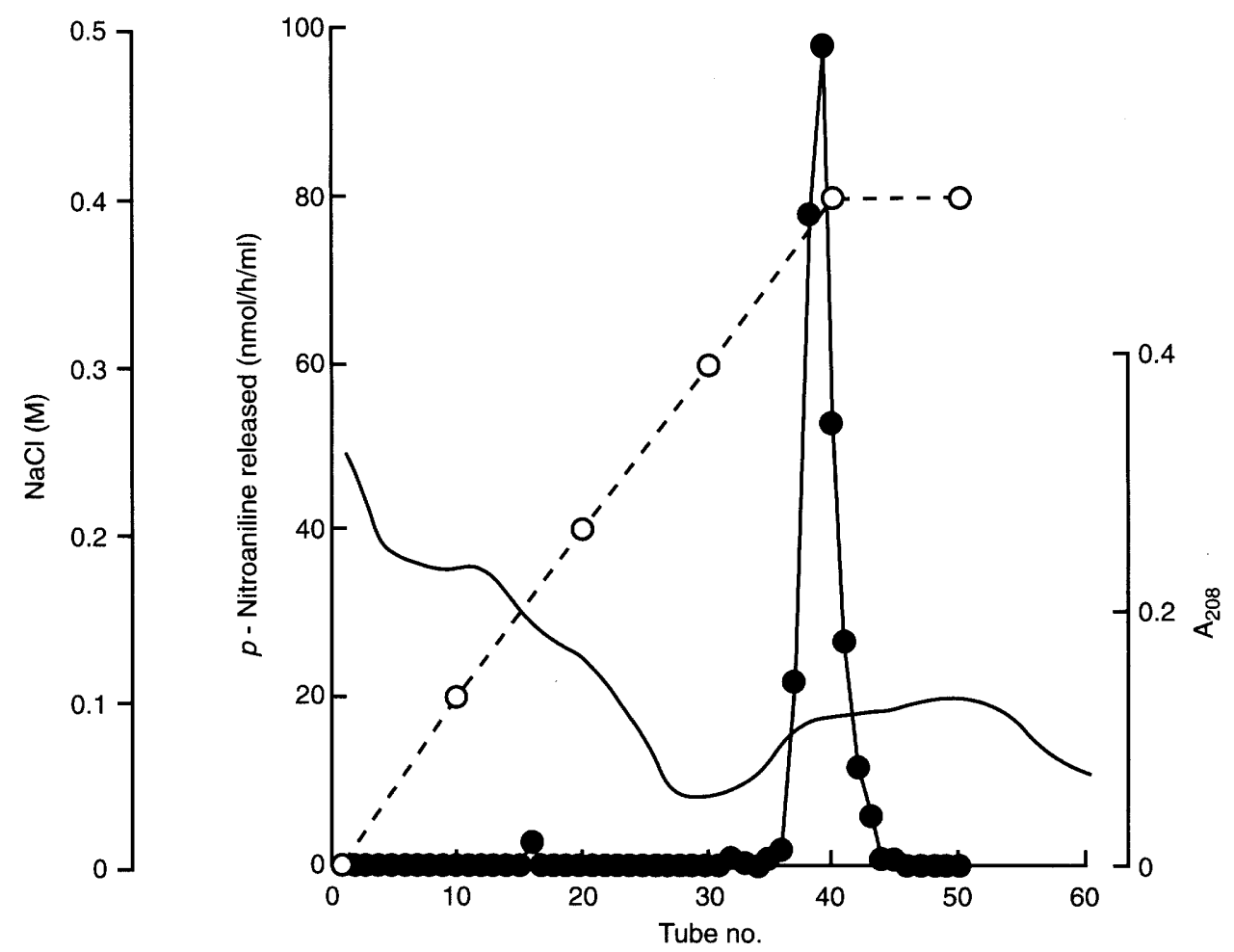

Fig. 5. Cation-exchange chromatography of glycylprolyl arylamidase; enzyme activity (๑), $\mathrm{NaCl}$ gradient $(\mathrm{O})$, the solid line shows protein absorbance at $208 \mathrm{~nm}$. Data shown are representative results from two experiments. 


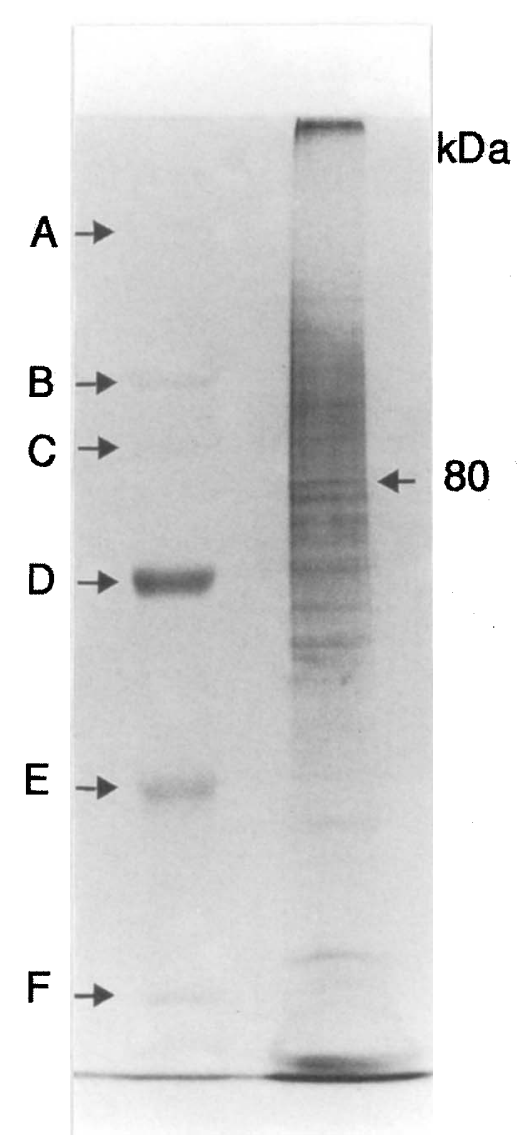

Fig. 6. SDS-PAGE of $B$. splanchnicus cell extracts. Mol. wt standards (kDa): A, myosin (205); B, $\beta$-galactosidase (116); C, phosphorylase B (97.4); D, bovine serum albumin (66); E, egg albumin (45); F, carbonic anhydrase (29).

that large amounts of GPA accumulated within the bacteria during exponential growth, and that approximately $40 \%$ of intracellular arylamidase activity was released from the bacteria before cells entered stationary phase (Fig. 1).

Studies with $B$. fragilis have shown that protease secretion at the end of active growth may be a response to N-limitation, and that release of these enzymes is a discrete process that is not associated with cell lysis [25]. These observations are supported to some extent by continuous culture data obtained in this study, where GPA synthesis by B. splanchnicus was shown to occur optimally during $\mathrm{N}$-limited growth (Fig. 2). The chemostats were used to control bacterial growth rates and regulate nutrient (glucose, ammonia) availability. Extracellular GPA activity was not detected in continuous cultures of B. splanchnicus, except for trace levels at the lowest dilution rates $(\mathrm{D}=<0.03 / \mathrm{h})$. This was probably a result of cell lysis or leakage, as the bacteria were growing under extremely nutrient-limiting culture conditions. The observation that GPA activity was completely cellbound in the chemostats indicates that release of the enzyme may have required a specific signal that was

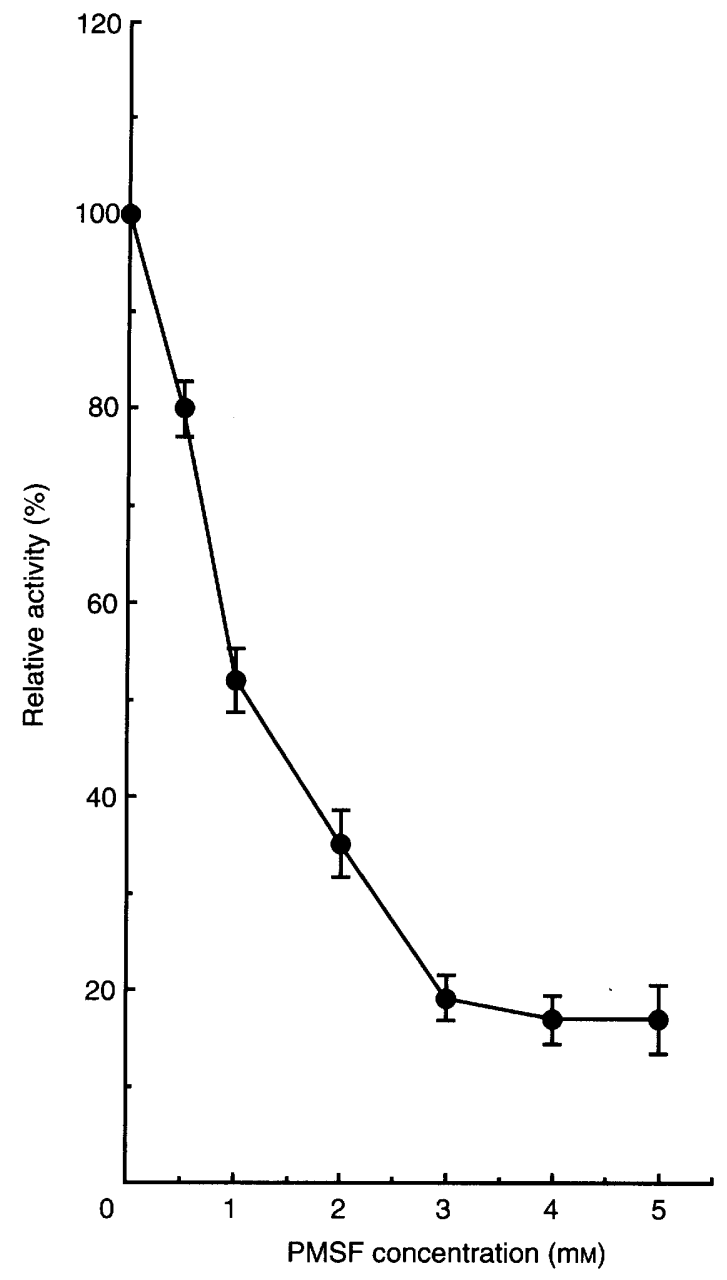

Fig. 7. Effect of phenylmethylsulphonyl fluoride (PMSF) concentration on inhibition of GPRPNA hydrolysis by partially purified (gel filtration) B. splanchnicus glycylprolyl arylamidase. Results are means from three experiments and $\mathrm{SD}$.

not present in very rapidly growing bacteria. As would be expected with a constitutive enzyme, GPA synthesis was growth rate-associated over the range of dilution rates examined $(D=0.025-0.29 / \mathrm{h})$, which correspond to cell doubling times of 27.7 and $2.4 / \mathrm{h}$, respectively.

Inhibition experiments indicated that $B$. splanchnicus NCTC 10825 constitutively produced a number of peptidolytic enzymes of the thiol, serine, and possibly, the metalloprotease type (Table 2). These enzymes exhibited arylamidase activity against a restricted number of chromogenic substrates, particularly VAPNA and GPRPNA, together with $\beta$-naphthylamidase activity towards glycylprolyl $\beta$-naphthylamide, demonstrating the existence of a glycylprolyl arylamidase. Thus, B. splanchnicus GPA manifests similar substrate specificities to dipeptidyl peptidase IV described in Streptococcus mitis [26] and glycylprolyl dipeptidylaminopeptidase in Porphyromonas gingivalis [27]. No significant activity was detected with glycine $p$ nitroanilide, proline naphthylamide, alanine $p$-nitro- 


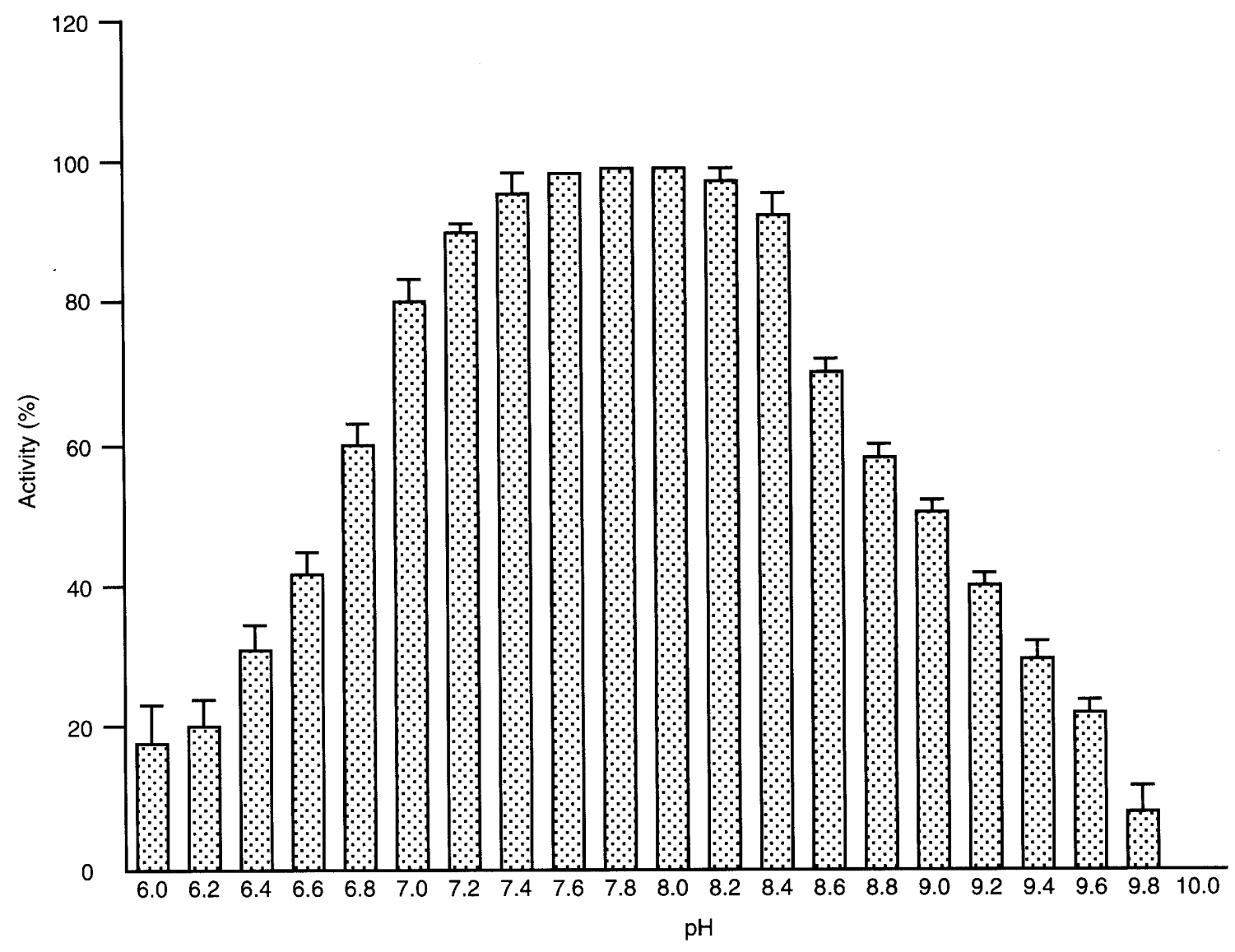

Fig. 8. Effect of $\mathrm{pH}$ on hydrolysis of GPRPNA by partially purified (gel filtration) B. splanchnicus glycylprolyl arylamidase. Data are mean values from three experiments and SD.

anilide or valine $p$-nitroanilide, demonstrating a high degree of specificity towards C-terminus substituted dipeptidyl substrates. The absence of inhibitory effects by elastinal, soybean trypsin inhibitor and chymostatin confirmed that peptidolytic enzymes produced by $B$. splanchnicus, including GPA, did not manifest elastase, trypsin or chymotrypsin-like characteristics.

Preparative isoelectric focusing of cell extracts gave a major peak (fraction 3, pH 3.51) and a minor peak (fraction 6, $\mathrm{pH} 3.95$ ) of activity for both GPRPNA and VAPNA hydrolysis. Azocasein was also hydrolysed by fraction 3 , which together with the sensitivity of azocasein hydrolysis to PMSF (Table 2), indicated a degree of general protease activity by GPA.

Gel filtration of cell extracts by HPLC gave only one peak of activity against both GPRPNA and VAPNA, with an approximate molecular mass of $160 \mathrm{kDa}$. Activity staining of SDS-PAGE gels resulted in one band of activity with an estimated molecular mass of c. $80 \mathrm{kDa}$, indicating GPA to be a dimer. Activity against VAPNA was also found here. In cationexchange chromatography to further investigate the enzyme, one peak of activity against GPRPNA was eluted from the column by $0.3 \mathrm{M} \mathrm{NaCl}$. This sample also contained the major peak of VAPNA hydrolysis which, with the isoelectric focusing and HPLC data, provided good evidence for a single enzyme that was active against both substrates.

Inhibitor studies with partially purified enzyme preparations from the gel-filtration column demonstrated strong inhibition by low concentrations of PMSF (Fig. 7). Measurements to determine the $\mathrm{pH}$ optimum of GPRPNA hydrolysis (Fig. 8) showed a broad band of activity in the slightly alkaline $\mathrm{pH}$ range (7.5-8.2) which, in conjunction with the inhibitor data, is consistent with $B$. splanchnicus GPA being a serine enzyme. Although GPRPNA hydrolysis was also inhibited by thimerosal (Table 2 ), the absence of inhibitory effects by iodoacetate would preclude it being a thiol protease. These results show that $B$. splanchnicus GPA shares a number of other characteristics with the glycylprolyl dipeptidylaminopeptidase produced by $P$. gingivalis, which is an extracellular serine enzyme that is sensitive to low concentrations of PMSF, and has a molecular mass of c. $160 \mathrm{kDa}[27]$.

A large but variable proportion of proteolytic and peptidolytic activity in the human large intestine is of bacterial origin [15], and these cell-associated and extracellular enzymes, particularly those produced by Bacteroides spp., play an important role in the microecology of the bowel $[6,8]$. The broad $\mathrm{pH}$ optimum 
of B. splanchnicus GPA, 7.5-8.2 (Fig. 8), is similar to the $\mathrm{pH}$ optima for general proteolytic activities in the large gut [28]. However, as intestinal contents are usually acid to neutral in $\mathrm{pH}$ [29], these enzymes must function sub-maximally in the colon. Therefore, factors that control intestinal $\mathrm{pH}$, such as short chain fatty acid production during carbohydrate fermentation, may be important in regulating proteolysis in the large intestine.

In conclusion, results presented here provide evidence for constitutive production of a glycylprolyl arylamidase by $B$. splanchnicus. In many respects, $B$. splanchnicus proteases appear to be very similar to those produced by members of the $B$. fragilis group $[10,13,25]$. The mechanism of release of intracellular GPA by this organism at the end of active growth is of particular interest, as the bacterium is a gramnegative species. Further work at the molecular and genetic level is needed to elucidate the mechanisms involved in GPA synthesis and secretion and, in particular, to identify the factors that signal arylamidase release.

\section{References}

1. Holdeman LV, Cato EP, Moore WEC. Anaerobe laboratory manual, 4th edn. Blacksburg, Virginia Polytechnic Institute and State University. 1977.

2. Finegold SM, Sutter VL, Mathisen GE. Normal indigenous intestinal flora. In: Hentges DJ (ed) Human intestinal microflora in health and disease. London, Academic Press. 1983: 3.

3. Jousimies-Somer HR, Finegold SM. Anaerobic Gram-negative bacilli and cocci. In: Balows A, Hausler WJ, Herrmann KL, Isenberg HD, Shadomy HJ (eds) Manual of clinical microbiology, 5th edn. Washington, DC, American Society for Microbiology. 1991: 538-553.

4. Macfarlane GT, Allison C, Gibson SAW, Cummings JH. Contribution of the microflora to proteolysis in the human large intestine. $J$ Appl Bacteriol 1988; 64: 37-46.

5. Macfarlane GT, Gibson GR. Characteristics of protease synthesis in Bacteroides splanchnicus NCTC 10825. Appl Microbiol Biotechnol 1993; 39: 506-511.

6. Macfarlane GT, Macfarlane S. Utilization of pancreatic trypsin and chymotrypsin by proteolytic and nonproteolytic Bacteroides fragilis-type bacteria. Curr Microbiol 1991; 23: $143-148$.

7. Macfarlane GT, Cummings JH, Macfarlane S, Gibson GR. Influence of retention time on degradation of pancreatic enzymes by human colonic bacteria grown in a 3-stage continuous culture system. J Appl Bacteriol 1989; 67: 520527.

8. Macfarlane S, Macfarlane GT. Proteolysis and amino acid fermentation. In: Gibson GR, Macfarlane GT (eds) Human colonic bacteria: role in nutrition, physiology and pathology. Boca Raton, CRC Press. 1995: 75.

9. Macfarlane GT, Cummings JH, Allison C. Protein degradation by human intestinal bacteria. $J$ Gen Microbiol 1986; 132. 1647-1656.

10. Gibson SAW, Macfarlane GT. Characterization of proteases formed by Bacteroides fragilis. J Gen Microbiol 1988; 134: 2231-2240.

11. Donelli G, Fabbri A, Fiorentini C. Bacteroides fragilis enterotoxin induces cytoskeletal changes and surface blebbing in HT-29 cells. Infect Immun 1996; 64: 113-119.

12. Riepe SP, Goldstein J, Alpers DH. Effect of secreted Bacteroides proteases on human intestinal brush border hydrolases. J Clin Invest 1980; 66: 314-322.

13. Gibson SAW, Macfarlane GT. Studies on the proteolytic activity of Bacteroides fragilis. J Gen Microbiol 1988; 134: 19-27.

14. Macfarlane GT, Englyst HN. Starch utilization by the human large intestinal microflora. J Appl Bacteriol 1986; 60: 195201.

15. Gibson SAW, McFarlan C, Hay S, Macfarlane GT. Significance of microflora in proteolysis in the colon. Appl Environ Microbiol 1989; 55: 679-683

16. Laemmli UK. Cleavage of structural proteins during the assembly of the head of bacteriophage T4. Nature 1970; 227: $680-685$.

17. Degnan BA, Macfarlane GT. Arabinogalactan utilization in continuous cultures of Bifidobacterium longum. Effect of coculture with Bacteroides thetaiotaomicron. Anaerobe 1995; 1: $103-112$.

18. Hazlewood GP, Edwards R. Proteolytic activities of a rumen bacterium, Bacteroides ruminicola R8/4. J Gen Microbiol 1981; 125: $11-15$

19. Umezawa $H$, Aoyagi T. Activities of proteinase inhibitors of microbial origin. In: Barrett AJ (ed) Proteinases in mammalian cells and tissues. Amsterdam, North Holland. 1977: 637.

20. Barrett AJ. Introduction to the history and classification of tissue proteinases. In: Barrett AJ (ed) Proteinases in mammalian cells and tissues. Amsterdam, North Holland. 1977: 1.

21. Matsubara H, Feder J. Other bacterial, mold and yeast proteases. In: Boyer PD (ed) The enzymes, vol 3. New York, Academic Press. 1971: 721.

22. Siefter S, Harper E. The collagenases. In: Boyer PD (ed) The enzymes, vol 3. New York, Academic Press. 1971: 649.

23. Webb JL. Mercurials. In: Enzyme and metabolic inhibitors, vol 2. New York, Academic Press. 1966: 729-985.

24. Liu PV, Hsieh H-C. Inhibition of protease production in various bacteria by ammonium salts: its effect on toxin production and virulence. $J$ Bacteriol 1969; 99: 406-413.

25. Macfarlane GT, Macfarlane S, Gibson GR. Synthesis and release of proteases by Bacteroides fragilis. Curr Microbiol 1992; 24: 55-60.

26. Fukasawa KM, Harada M. Purification and properties of dipeptidyl peptidase IV from Streptococcus mitis ATCC 9811. Arch Biochem Biophys 1981; 210: 230-237.

27. Abiko Y, Hayakawa M, Murai S, Takiguchi H. Glycylprolyl dipeptidylaminopeptidase from Bacteroides gingivalis. J Dent Res 1985; 64: 106-111.

28. Macfarlane GT, Allison C, Gibson GR. Effect of $\mathrm{pH}$ on protease activities in the large intestine. Lett Appl Microbiol 1988; 7: $161-164$

29. Cummings JH, Pomare EW, Branch WJ, Naylor CPE, Macfarlane GT. Short chain fatty acids in human large intestine, portal, hepatic and venous blood. Gut 1987; 28: $1221-1227$ 